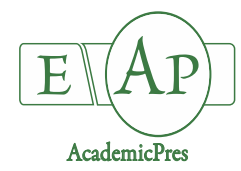

Sariñana-Aldaco O et al. $(2020)$
Notulae Botanicae Horti Agrobotanici Cluj-Napoca 48(2):882-892
DOI: $10.15835 /$ nbha48211914
Research Article

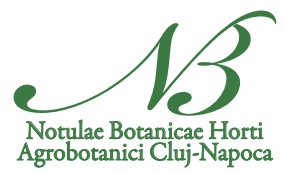

\title{
Improvement of the nutraceutical quality and yield of tomato by application of salicylic acid
}

\author{
Oscar SARIÑANA-ALDACO ${ }^{1}$, Esteban SANCHEZ-CHAVEZ ${ }^{2}$, \\ Manuel FORTIS-HERNÁNDEZ ${ }^{1}$, José Antonio GONZÁLEZ- \\ FUENTES $^{3}$, Alejandro MORENO-RESENDEZ ${ }^{3}$, \\ Alfonso ROJAS-DUARTE ${ }^{3}$, Pablo PRECIADO-RANGEL ${ }^{1 *}$

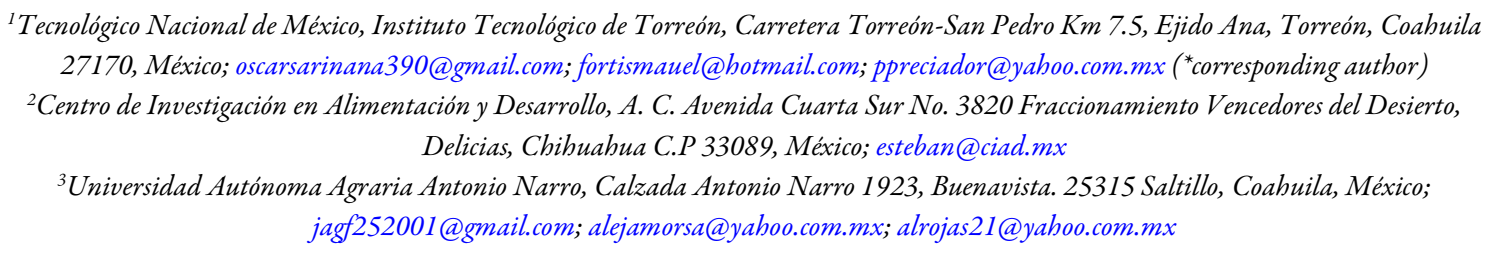

\begin{abstract}
Tomato fruits are a unique functional food and a natural reservoir of nutrients, antioxidants, vitamins and bioactive compounds that improve nutrition and human health. As an important vegetable throughout the world, tomatoes have attracted the attention of researchers to carry out various strategies to improve the functionality of this food aimed at the prevention of diseases, health and global well-being. An agronomic strategy in this study was to evaluate the influence of the application of "salicylic acid (SA)" on the yield and nutraceutical quality of the tomato crop, produced under hydroponic conditions. A completely randomized experimental design with six repetitions was used. SA at five doses $(0.025,0.05,0.075,0.1$ and $0.125 \mathrm{mM})$ and one control were applied every 15 days in the nutritive solution under a hydroponic system on tomato plants. The evaluated variables were yield (total fruit weight per plant), fruit parameters (weight, diameter, firmness, and total soluble solids), percentage of weight loss and nutraceutical quality of tomato. The results obtained indicate that the addition of salicylic acid in nutritive solution increased the yield and biosynthesis of phytochemical compounds in tomato fruits, in relation to the control without application. In conclusion, to obtain a higher nutraceutical quality without affecting the tomato fruit yield, it is recommended to use the average concentration $(0.125 \mathrm{mM})$ of SA.
\end{abstract}

Keywords: biostimulation; elicitors; human health; nutrient solution; phytochemicals

\section{Introduction}

Tomato (Solanum lycopersicum L.) is the most cultivated vegetable worldwide, since it is the main ingredient in traditional and processed foods, in addition to the important nutraceutical content that this fruit 
contains (Islam et al., 2018). Yields and quality are heterogeneous due to genotypic variations, environmental conditions, production system, pests and diseases, which negatively impacts grower's economy (Pandey et al., 2017; Rai, 2020).

In Mexico, the largest production is centred in the Northwest states, and to a lesser extent in the West (Rios-Osorio et al., 2014). In these areas of the country, tomato production in hydroponic systems under greenhouses has increased markedly in recent years (De la Rosa-Rodríguez et al., 2016). With these cultivation systems, increments in productivity have been achieved, however, the nutraceutical quality of the produce is not always related to these increases (Preciado-Rangel et al., 2018).

Elicitors use is a technique that allows to improve the synthesis of bioactive compounds in vegetables without compromising crop yield (Larqué-Saavedra and Martin-Mex, 2007; Wang et al., 2015; Wen et al., 2019). Salicylic acid (SA) stands out among the most promising elicitors to stimulate crop development and production, which has been shown to induces resistance to any type of stress (Xu et al., 2009), improves development of plants (Yusuf et al., 2013), improves photosynthetic action (Shah et al., 2019), increases yield (Semida et al., 2017) and the shelf life of fruits and the nutraceutical quality (Chen et al., 2016; Ennab et al., 2020).

Therefore, the objective of this research work was to determine the effect of the addition of SA via nutrient solution on the yield, percentage of weight loss and nutraceutical quality of tomato fruits grown under hydroponic conditions.

\section{Materials and Methods}

\section{Plant material and growing conditions}

The study was carried out in a circular greenhouse, covered with plastic polyethylene and a cooling system, located at the Technological Institute of Torreón, Mexico $\left(24^{\circ} 30^{\prime}\right.$ and $27^{\circ}$ north latitude, $102^{\circ} 00^{\prime}$ and $104^{\circ} 40^{\prime}$ west longitude, at an altitude of $1,120 \mathrm{~m}$ ). Sahel hybrid ${ }^{\circ}$ tomato seedlings with six true leaves were transplanted into $15 \mathrm{~kg}$ capacity black polyethylene plastic pots of 500 gauge, which contained river sand and perlite (80:20) as growing media. The river sand was washed and disinfected with a 5\% sodium hypochlorite solution. The pots were placed in a double row, in a staggered arrangement, where a density of four plants per square meter was obtained. A drip irrigation system was used to provide three irrigations per day, with each plant receiving $0.6 \mathrm{~L}$ every irrigation event, from transplant to start of flowering and 2.5 to $3.5 \mathrm{~L}$ from flowering to harvest. The plants were guided to a single stem and to support them, they were tutored with raffia attached to the upper part of the greenhouse structure. Pollination was performed with an electric brush daily, since the beginning of flowering until the fruit was set.

\section{Experimental design and treatments}

The experimental design used was completely randomized with six treatments $(0,0.025,0.05,0.075,0.1$ and $0.125 \mathrm{mM}$ of SA), where each concentration had six replicates. SA treatments were applied every 15 days via the nutrient solution (Steiner, 1984), after transplant, obtaining a total of seven applications of SA. The $\mathrm{pH}$ and electrical conductivity were maintained at 5.5 and $2.0 \mathrm{dS} \mathrm{m}^{-1}$ respectively. The response variables were yield and its components, percentage of weight loss and nutraceutical quality of the fruit.

Yield

The fruits from each treatment were harvested since the first to the fifth tomato cluster when the fruit presented an intense red colour. 


\section{Fruit quality}

The quality of the fruit was evaluated in three fruits taken at random from each cluster corresponding to each replicate of the treatments, measuring the average weight of the fruit, the polar and equatorial fruit diameter, firmness of the fruit, weight loss and total soluble solids.

\section{Fruit firmness}

It was determined with a penetrometer (Fruit Hardness Tester FHT200), with an $8 \mathrm{~mm}$ diameter strut, readings were taken on the opposite sides of the fruit and an average was obtained, the results were expressed in Newton units (N).

\section{Weight loss}

Weight loss was determined in a sample of 10 fruits acquired from the last tomato cluster harvested. The fruits, under laboratory environmental conditions, seven days after the harvest its weight loss was determined with a scale (Bapred-3 Rhino brand). The difference with respect to the initial weight was obtained, reporting it in percentage.

\section{Total soluble solids (TSS)}

They were evaluated in ${ }^{\circ} \mathrm{Brix}$, for this, a drop of fruit juice was obtained and the reading was determined with a manual refractometer from 0 to $32 \%$ (Master 2311).

\section{Nutraceutical quality of the fruit}

Total phenols

They were measured by colorimetry using the Folin-Ciocalteau method, proposed by Singlenton et al. (1985). Phenols from a $0.5 \mathrm{~g}$ sample were extracted with methanol. $750 \mu \mathrm{L}$ of $\mathrm{Na}_{2} \mathrm{CO}_{3}$ at $2 \%$ was added in a test tube, followed by the addition of $250 \mu \mathrm{l}$ at $50 \%$ of Folin-Ciocalteau reagent, plus a final volume of 1,375 $\mu \mathrm{L}$ of deionized $\mathrm{H}_{2} \mathrm{O}$, adding $250 \mu \mathrm{L}$ of enzyme extract. Total phenol results were expressed in mg of gallic acid $\mathrm{g}^{-1}$.

\section{$\underline{\text { Total flavonoids }}$}

Determination was performed following the method of Zhishen et al. (1999). Compounds were extracted with methanol. An amount of $0.5 \mathrm{~g}$ was homogenized with $5 \mathrm{~mL}$ of methanol. It was centrifuged at $4,000 \mathrm{rpm}$ for $10 \mathrm{~min}$ at $4{ }^{\circ} \mathrm{C}$. For the mixture, $250 \mu \mathrm{L}$ of the aliquot was placed in a test tube, followed by the addition of $75 \mu \mathrm{L}$ of $\mathrm{NaNO}_{2}$ and stirred by a vortex. After $5 \mathrm{~min} 150 \mu \mathrm{L}$ of $\mathrm{AlCl}_{3}$ was added; then, a volume of $500 \mu \mathrm{L}$ of $\mathrm{NaOH}$ was added, plus a final volume of 2,025 of $\mathrm{H}_{2} \mathrm{O}$. Absorbance was immediately measured by at $510 \mathrm{~nm}$ spectrophotometry. Flavonoids were quantified based on a standard catechin curve.

\section{Antioxidant capacity}

It was determined by the method proposed by Hsu et al. (2003), using the free radical 1,1-diphenyl-2picril-hydracil (DPPH), which has an absorption maximum of $517 \mathrm{~nm}$. The extract was obtained by macerating $1 \mathrm{~g}$ of seed in $5 \mathrm{~mL}$ at $80 \%$ methanol, and then centrifuged at $6,000 \mathrm{rpm}$ for $10 \mathrm{~min}$ at a temperature of $4{ }^{\circ} \mathrm{C}$. Afterward $0.5 \mathrm{~mL}$ of the extract was taken from the resulting supernatant. Finally, it was mixed with $2.5 \mathrm{~L}$ of freshly prepared $0.1 \mathrm{mM} \mathrm{DPPH}$ solution, which was incubated for $60 \mathrm{~min}$ in the dark and cold. Absorbance was measured by at $517 \mathrm{~nm}$ spectrophotometry. The values of the DPPH test were obtained with the formula:

Inhibition percentage $=(1-\mathrm{X})^{*} 100$

$\mathrm{X}=\mathrm{A}_{517}$ samples $/ \mathrm{A}_{517}$ blank

Results are expressed in percent inhibition 


\section{Lycopene extraction}

It was by the method of Fish et al. (2002) with some modifications. Approximately $1 \mathrm{~g}$ of sample (seedless) was placed in test tubes covered with $50 \mathrm{~mL}$ PTFE aluminium while on ice. Lycopene extraction solution $(39 \mathrm{~mL})$ consisting of hexane, $0.05 \%(\mathrm{w} / \mathrm{v})$ butylated hydroxytoluene (BHT) in acetone, and $95 \%$ ethanol in a 1:1:1 ratio was added to the tubes and stirred for $10 \mathrm{~min}$ at $180 \mathrm{rpm} .6 \mathrm{~mL}$ of cold distilled water was added to each tube and stirred for an additional $5 \mathrm{~min}$ for better separation of polar and nonpolar compounds. The tubes were then removed from the stirring and left for $15 \mathrm{~min}$ at room temperature for separation into polar and non-polar layers. The supernatant was placed in new $15 \mathrm{~mL}$ aluminium-covered test tubes and kept at $-80^{\circ} \mathrm{C}$ for other experiments. The absorbance of the supernatant (hexane layer) containing lycopene was read three times using the spectrophotometer at a wavelength of $503 \mathrm{~nm}$. Absolute hexane was used as a blank. The amounts of lycopene in the tissues were estimated using the following formula:

Lycopene $\left(\mathrm{mg} \mathrm{kg}^{-1}\right)=(\mathrm{x} / \mathrm{y}) \times \mathrm{A}_{503} \times 3.12$

Where $x$ is the amount of hexane $(\mathrm{mL})$, and the weight of the sample, $A_{503}$ the absorbance at $503 \mathrm{~nm}$ and 3.12 the extinction coefficient.

$\underline{\text { Vitamin C }}$

It was obtained by means of the titration method proposed by Padayatt et al. (2001). Fresh fruit samples of $10 \mathrm{~g}$ were used, which were crushed using $10 \mathrm{~mL}$ at $2 \%$ of hydrochloric acid, filtered and then in a flask Erlenmeyer was adjusted to $100 \mathrm{~mL}$ using distilled water. Subsequently, with $10 \mathrm{~mL}$ of the diluted, it was titrated using 2,6 dichlorophenolindophenol $\left(1 \times 10^{-3} \mathrm{~N}\right)$ to determine the content of vitamin $\mathrm{C}$ using the formula:

Vit $\mathrm{C}(\mathrm{mg} 100 \mathrm{~g} \mathrm{FW})=(\mathrm{mL} 2.6$ dichlorophenolindophenol $)(0.088)$

(total volume)(100)/(volume of aliquot)(weight of sample)

\section{Statistical analysis}

The results obtained were analysed by analysis of variance and the comparison of means with the Tukey test $(\mathrm{p} \leq 0.5)$ using the statistical package SAS, version 9.1 (SAS Institute, 2004).

\section{Results and discussion \\ Yield}

The use of SA modified the yield and its components, the highest yield was in the plants treated with the $0.025 \mathrm{mM}$ dose of SA, being $27.43 \%$ higher than the control treatment; this increase is caused by an increase in weight and fruits per plant (Table 1). Wada and Takeno (2013) published similar results indicating that AS improves flowering, hence ensuring more fruits per plant and of greater size and weight, since the application of AS accelerates the cell division of all organs in general (Ahmadi et al., 2014). Preciado-Rangel et al. (2019) reported an increase in performance when using low doses; while high doses decrease it. The plant's response to $\mathrm{SA}$ is concentration-dependent, since at low doses performance is promoted and moderate doses improve fruit quality characteristics and induce resistance to stress, while higher concentrations can cause cell death (Tounekti et al., 2013). Even though this effect was not observed in the results, it is possible that a phytotoxicity threshold has not been reached, since being within this threshold causes stress that the plant cannot control (Hayat et al., 2010). 
Table 1. Yield components by effect of the different concentrations of SA in the nutrient solution

\begin{tabular}{|c|c|c|c|c|c|}
\hline $\begin{array}{c}\text { Salicylic acid } \\
(\mathrm{mM})\end{array}$ & NF & $\begin{array}{c}\text { FW } \\
(\mathrm{g})\end{array}$ & $\begin{array}{c}\text { PD } \\
(\mathrm{mm})\end{array}$ & $\begin{array}{c}\text { ED } \\
(\mathrm{mm})\end{array}$ & $\begin{array}{c}\text { Yield } \\
\left(\mathrm{kg} \mathrm{plant}^{-1}\right)\end{array}$ \\
\hline Control & $23.0 \pm 1.78 \mathrm{~b}^{*}$ & $98.1 \pm 5.29 \mathrm{~b}^{*}$ & $58.8 \pm 2.28 \mathrm{~b}^{*}$ & $43.4 \pm 1.90 \mathrm{~d}^{*}$ & $2.26 \pm 0.27 \mathrm{~b}^{*}$ \\
\hline 0.025 & $25.6 \pm 1.86 \mathrm{a}$ & $112.5 \pm 11.67 \mathrm{a}$ & $64.9 \pm 5.07 \mathrm{a}$ & $47.7 \pm 1.81 \mathrm{ab}$ & $2.88 \pm 0.34 \mathrm{a}$ \\
\hline 0.05 & $24.6 \pm 1.63 \mathrm{ab}$ & $108.9 \pm 7.71 \mathrm{a}$ & $62.6 \pm 5.24 \mathrm{ab}$ & $45.2 \pm 2.47 \mathrm{~cd}$ & $2.69 \pm 0.34 \mathrm{a}$ \\
\hline 0.075 & $25.3 \pm 1.96 \mathrm{a}$ & $107.6 \pm 8.48 \mathrm{ab}$ & $61.4 \pm 4.41 \mathrm{ab}$ & $47.4 \pm 2.09 \mathrm{a} \mathrm{bc}$ & $2.72 \pm 0.33 \mathrm{a}$ \\
\hline 0.1 & $25.6 \pm 1.86 \mathrm{a}$ & $106.9 \pm 4.97 \mathrm{ab}$ & $62.3 \pm 3.11 \mathrm{ab}$ & $46.0 \pm 2.17 \mathrm{bc}$ & $2.74 \pm 0.23 \mathrm{a}$ \\
\hline 0.125 & $25.1 \pm 2.40 \mathrm{ab}$ & $108.3 \pm 8.58 \mathrm{a}$ & $63.0 \pm 4.18 \mathrm{ab}$ & $48.5 \pm 1.26 \mathrm{a}$ & $2.74 \pm 0.41 \mathrm{a}$ \\
\hline
\end{tabular}

${ }^{*}$ Different letters within each column show significant statistical difference (Tukey, $\mathrm{p} \leq 0.05$ ). NF = number of fruits;

$\mathrm{FW}=$ fruit weight $\mathrm{PD}=$ polar diameter; $\mathrm{ED}=$ equatorial diameter.

\section{Fruit quality, firmness and weight loss}

The firmness in the fruits confers the capacity to resist blows during their transport or commercialization, in addition of increasing their shelf life. The use of the SA improved firmness and decreased fruit weight loss (Table 2); the firmness in the treated fruits with the $0.125 \mathrm{mM}$ dose of SA was $75.3 \%$ higher than those of the control treatment. Similar results were informed by Islam et al. (2018) who reported an increase in firmness of cherry tomato fruits with SA use, an effect attributed to decreased ethylene production and inhibition of the action of the enzymes responsible for cell wall degradation, such as cellulase (CEL), pectin-methyl esterase (PME) and polygalacturonase (PG) that depend on ethylene, the phytohormone responsible for fruit ripening (Asghari and Aghdam, 2010). Fruits with less firmness are susceptible to rapid wilting and dehydration (Moreno-Velázquez et al., 2013), thus causing greater weight loss, which is due to loss of water by perspiration and metabolites by respiration (Sahu et al., 2016); SA produces an inhibitory effect on climacteric respiration and ethylene production, which increases the shelf life and reduces the weight loss of the fruits (Kant and Arora, 2014).

Table 2. Quality of tomato fruits due to the effect of SA in the nutrient solution

\begin{tabular}{|c|c|c|}
\hline Salicylic acid $(\mathrm{mM})$ & Firmness $(\mathrm{N})$ & Weight loss \% \\
\hline Control & $6.6 \pm 0.4 \mathrm{~d}^{*}$ & $13.5 \pm 3.66 \mathrm{a}^{*}$ \\
\hline 0.025 & $8.1 \pm 0.5 \mathrm{c}$ & $11.8 \pm 5.92 \mathrm{~b}$ \\
\hline 0.05 & $8.3 \pm 0.7 \mathrm{c}$ & $10.1 \pm 2.31 \mathrm{~b}$ \\
\hline 0.075 & $9.8 \pm 1.0 \mathrm{~b}$ & $7.9 \pm 2.7 \mathrm{c}$ \\
\hline 0.1 & $9.7 \pm 0.8 \mathrm{~b}$ & $8.1 \pm 2.47 \mathrm{c}$ \\
\hline 0.125 & $11.5 \pm 1.1 \mathrm{a}$ & $6.1 \pm 1.20 \mathrm{~d}$ \\
\hline
\end{tabular}

${ }^{*}$ Different letters within each column show significant statistical difference (Tukey, $\mathrm{p} \leq 0.05$ ). $\mathrm{N}=$ Newton.

Total soluble solids (TSS)

The TSS content is used commercially as an index of fruit quality because it has a high positive correlation with the sugar content ( $\mathrm{Li}$ et al., 2016). The results confirm that the use of the SA increases the soluble solids in tomato fruits (Figure 1A). The highest TSS values are obtained with the doses of 0.075 and $0.1 \mathrm{mM}$, which exceed $21.31 \%$ of the fruits compared to the control treatment. The results are consistent with those reported by Islam et al. (2018) and Peyro et al. (2017) who informed a greater accumulation of TSS in fruits exposed to SA. Ahmad et al. (2013) pointed out that the increase in TSS was due to the fact that SA improves the efficiency of the rubisco enzyme and increases the content of chlorophyll, therefore, the rate of photosynthesis increases and this is directly reflected in the accumulation of photo-assimilates in the fruits, increasing the TSS. 

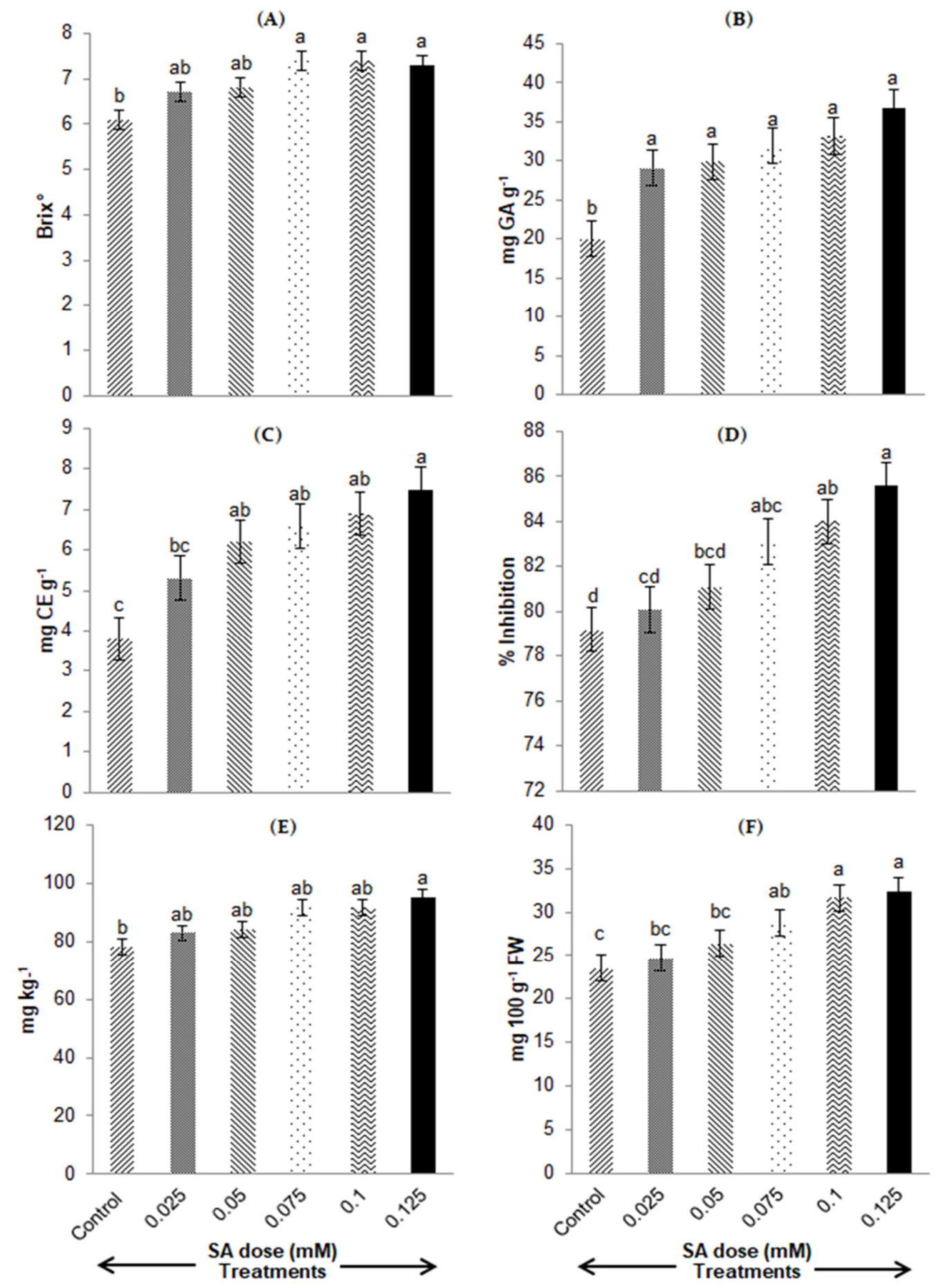

Figure 1. Effect of different doses of salicylic acid on the content of total soluble solids (A), total phenols $(B)$, total flavonoids $(C)$, antioxidant capacity $(D)$, lycopene $(\mathrm{E})$ and vitamin $C(F)$ in tomato fruits. ${ }^{*}$ Different letters within each column show significant statistical difference (Tukey, $\mathrm{p} \leq 0.05$ ) 


\section{Nutraceutical quality of the fruits}

Total phenols and flavonoids

With the increment in SA concentration, total flavonoid and phenolic compounds increased (Figure $1 \mathrm{~B}$ and $1 \mathrm{C}$ ), obtaining the highest amount of these metabolites with a concentration of $0.125 \mathrm{mM}$, exceeding the control treatment by 79.5 and $97.36 \%$, respectively. Radwan et al. (2019) mention that SA stimulates the synthesis of phenolic compounds, since the appropriate concentrations causes biochemical stress on cell suspensions and improves activity phenylalanine ammonium lyase (PAL) which is an important enzyme in the synthesis of these metabolites (Kong, 2015). Obtaining foods rich in phenolic compounds is desirable in the food industry, since these compounds delay oxidation and lipids degradation increase the quality of food (Argueta-Solís et al., 2018). Their consumption is beneficial for human health, due to their anti-cancer, antiinflammatory and antimicrobial characteristics (Rodríguez-Carpena et al., 2011; Saeed et al., 2012; Surh, 2018), in addition to the fact that they tend to fight cardiovascular diseases (Wolfe and Liu, 2007).

\section{Total antioxidant capacity}

Antioxidants are substances naturally present in food, which prevent adverse effects of reactive oxygen species on the physiological functions of humans (Wilson et al., 2017). The results showed an $8.0 \%$ increase in antioxidant capacity (Figure 1D) in the fruits treated with the 0.125 dose, in relation to the fruits of the control treatment. It has been shown that adequate doses of $S A$ increase the content of bioactive compounds in fruits since the secondary metabolism is activated and increase the synthesis of total antioxidants (Larqué-Saavedra et al., 2010; Mora-Herrera et al., 2011). Hayat et al. (2008) reported that the application of SA improves the activity of antioxidant enzymes such as superoxide dismutase, peroxidase and catalase, which represent the first level of defence in plants.

\section{Lycopene}

Lycopene is a carotenoid that is found mainly in tomato, it has antioxidant, anti-inflammatory and chemotherapeutic effects on cardiovascular, neurodegenerative diseases and some types of cancer (Przybylska, 2020). The dose of $0.125 \mathrm{mM}$ of SA improved the concentration of lycopene in fruits (Figure $1 \mathrm{E}$ ) by $22 \%$, in relation to untreated fruits. The results are consistent with those stated by Javaheri et al. (2012) who reported significant increases in lycopene content in tomato with the use of SA. This quality variable is related to antioxidant capacity, which is well known to increase under stress conditions due to the role it plays in neutralizing oxidizing compounds (Tokunaga et al., 2004).

\section{Vitamin C}

Ascorbic acid is the most plentiful water-soluble antioxidant found in plants (Yactayo-Chang et al., 2017 ) and $91 \%$ of the requirements come from the consumption of plant products (Tareen et al., 2012). The use of $S A$ significantly improved the vitamin $\mathrm{C}$ content in tomato fruits (Figure $1 \mathrm{~F}$ ), the highest values were obtained with the $0.125 \mathrm{mM}$ dose, exceeding the control by $37.81 \%$. Similar works have reported increases in ascorbic acid in strawberry fruits (Mohamed et al., 2018), tomato (Javaheri et al., 2012), potato (Elwan and ElHamahmy, 2009) and Granada (Mirdehghan and Ghotbi, 2014) when is treated with SA. This behaviour is due to the fact that $\mathrm{SA}$ increases the concentration of sugars, such as glucose, which is a precursor compound of vitamin C, which causes it to accumulate in the plant (Baldet et al., 2013).

\section{Conclusions}

The application of salicylic acid through the nutritive solution increased the yield and nutraceutical quality of tomato fruits. The addition of salicylic acid in the nutritive solution is an effective method to 
stimulate the synthesis of phytochemical compounds and obtain fruits with higher nutraceutical qualities. It is proposed to increase the concentrations of salicylic acid in nutritive solution to determine the dose where the response is non-linear.

\section{Authors' Contributions}

Conceptualization: OSA, PPR; Methodology: OSA, PPR, ESC; Validation: AMR, JAGF; Formal analysis: MFH, ARD; Investigation: OSA; Data curation: PPR, MFH; Funding acquisition: PPR, ESC; Project administration: PPR, ESC; Writing: OSA, PPR; Review and editing; PPR, JAGF. All authors read and approved the final manuscript.

\section{Acknowledgments}

Oscar Sariñana Aldaco acknowledges financial support given by the National Council for Science and Technology of México (CONACYT) for graduate study.

\section{Conflicts of Interest}

The authors declare that there are no conflicts of interest related to this article.

\section{References}

Ahmad S, Singh Z, Khan AS, Iqbal Z (2013). Pre-harvest application of salicylic acid maintain the rind textural properties and reduce fruit rot and chilling injury of sweet orange during cold storage. Pakistan Journal of Agricultural Sciences 50(4):559-569.

Ahmadi B, Shariatpanahi ME, Da Silva JAT (2014). Efficient induction of microspore embryogenesis using abscisic acid, jasmonic acid and salicylic acid in Brassica napus L. Plant Cell, Tissue and Organ Culture 116(3):343-351. https://doi.org/10.1007/s1 1240-013-0408-x

Argueta-Solís MG, Aguilar CN, Pintor-Ibarra LF, Chávez-González M, Rojas-Molina R, Wong-Paz JE, ... Rutiaga-Quiñones JG (2018). Inhibición de la oxidación de lípidos y constituyentes fenólicos relacionados en la madera y la corteza de tres especies de encino (Quercus candicans, Q. laurina y Q. rugosa). [Inhibition of lipid oxidation and related phenolic constituents in the wood and bark of three oak species (Quercus candicans, Q. laurina and Q. rugosa)]. Agrociencia 52(5):757-766.

Asghari M, Aghdam MS (2010). Impact of salicylic acid on post-harvest physiology of horticultural crops. Trends in Food Science \& Technology 21(10):502-509. https://doi:10.1016/j.tifs.2010.07.009

Baldet P, Bres C, Okabe Y, Mauxion JP, Just D, Bournonville C, ... Rothan C (2013). Investigating the role of vitamin C in tomato through TILLING identification of ascorbate-deficient tomato mutants. Plant Biotechnology 30(3):309-314. https://doi:10.5511/plantbiotechnology. 13.0622b

Chen Y, Cui J, Li G, Yuan M, Zhang Z, Yuan S, Zhang H (2016). Effect of salicylic acid on the antioxidant system and photosystem II in wheat seedlings. Biologia Plantarum 60(1):139-147. https://doi.org/10.1007/s10535-015-0564-4

De la Rosa-Rodríguez R, Lara-Herrera A, Lozano-Gutiérrez J, Padilla-Bernal LE, Avelar-Mejía JJ, Castañeda-Miranda R (2016). Rendimiento y calidad de tomate en sistemas hidropónicos abierto y cerrado. [Yield and quality of tomato in open and closed hydroponic systems]. Revista Mexicana de Ciencias Agrícolas (17):3439-3452.

Elwan MWM, El-Hamahmy MAM (2009). Improved productivity and quality associated with salicylic acid application in greenhouse pepper. Scientia Horticulturae 122(4):521-526. https://doi:10.1016/j.scienta.2009.07.001 
Ennab HA, El-Shemy MA, Alam-Eldein SM (2020). Salicylic acid and putrescine to reduce post-harvest storage problems and maintain quality of murcott mandarin fruit. Agronomy 10(1):115. https://doi.org/10.3390/agronomy10010115

Fish WW, Perkins-Veazie P, Collins JK (2002). A quantitative assay for lycopene that utilizes reduced volumes of organic solvents. Journal of Food Composition and Analysis 15:309-317. https://doi.org/10.1006/jfca.2002.1069

Hayat S, Hasan SA, Fariduddin Q, Ahmad A (2008). Growth of tomato (Lycopersicon esculentum) in response to salicylic acid under water stress. Journal of Plant Interactions 3(4):297-304. https://doi:10.1080/17429140802320797

Hayat Q, Hayat S, Irfan M, Ahmad A (2010). Effect of exogenous salicylic acid under changing environment: A review. Environmental and Experimental Botany 68(1):14-25. https://doi:10.1016/j.envexpbot.2009.08.005

Hsu CL, Chen W, Weng YM, Tseng CY (2003). Chemical composition, physical properties, and antioxidant activities of yam flours as affected by different drying methods. Food Chemistry 83(1):85-92. https://doi.org/10.1016/S03088146(03)00053-0

Islam MZ, Mele MA, Choi KY, Baek JP, Kang H (2018). Salicylic acid in nutrient solution influence the fruit quality and shelf life of cherry tomato grown in hydroponics. Sains Malaysiana 47(3):537-542. https://doi.org/10.17576/jsm-2018-470314

Islam MZ, Mele MA, Baek JP, Kang HM (2018). Iron, iodine and selenium effects on quality, shelf life and microbial activity of cherry tomatoes. Notulae Botanicae Horti Agrobotanici Cluj-Napoca 46(2):388392. https://doi:10.15835/nbha46211012

Javaheri M, Mashayekhi K, Dadkhah A, Tavallaee FZ (2012). Effects of salicylic acid on yield and quality characters of tomato fruit (Lycopersicum esculentum Mill.). International Journal of Agriculture and Crop Sciences 4(16):1184-1187.

Kant K, Arora A (2014). Effects of salicylic acid on postharvest physiology of tomato. Indian Journal of Horticulture 71(2):247252.

Kong JQ (2015). Phenylalanine ammonia-lyase, a key component used for phenylpropanoids production by metabolic engineering. RSC Advances 5(77):62587-62603. https://doi:10.1039/C5RA08196C

Larqué-Saavedra A, Martin-Mex R (2007). Effects of salicylic acid on the bioproductivity of plants. In: Hayat S, Ahmad A (Eds). Salicylic Acid-A Plant Hormone. Springer: Dordrecht, Netherlands pp 15-23.

Larqué-Saavedra A, Martín-Mex R, Nexticapan-Garcéz Á, Vergara-Yoisura S, Gutiérrez-Rendón M (2010). Efecto del ácido salicílico en el crecimiento de plántulas de tomate (Lycopersicon esculentum Mill.). [Effect of salicylic acid on the growth of tomato (Lycopersicon esculentum Mill.) seedlings]. Revista Chapingo Serie Horticultura 16(3):183-187.

Li JL, Sun DW, Cheng JH (2016). Recent advances in nondestructive analytical techniques for determining the total soluble solids in fruits: a review. Comprehensive Reviews in Food Science and Food Safety 15(5):897-911. https://doi.org/10.1111/1541-4337.12217

Mirdehghan SH, Ghotbi F (2014). Effects of salicylic acid, jasmonic acid, and calcium chloride on reducing chilling injury of pomegranate (Punica granatum L.) fruit. Journal of Agricultural Science and Technology 16:163-173.

Mohamed R, Abdelbaset AK, Abd-Elkader D (2018). Salicylic acid effects on growth, yield, and fruit quality of strawberry cultivars. Journal of Medicinally Active Plants 6(2):1-11. https://scholarworks.umass.edu/jmap/vol6/iss $2 / 2$

Mora-Herrera ME, Peralta-Velázquez J, López-Delgado HA, García-Velasco R, González-Díaz JG (2011). Efecto del ácido ascórbico sobre crecimiento, pigmentos fotosintéticos y actividad peroxidasa en plantas de crisantemo. [Effect of ascorbic acid on growth, photosynthetic pigments and peroxidase activity of Chrisantemum plants]. Revista Chapingo Serie Horticultura 17(2):73-81.

Moreno-Velázquez D, Cruz-Romero W, García-Lara E, Ibañez-Martínez A, Barrios-Díaz JM, Barrios-Díaz B (2013). Cambios fisicoquímicos poscosecha en tres cultivares de pepino con y sin película plástica. [Postharvest physicochemical changes in three cucumber cultivars with and without plastic film]. Revista Mexicana de Ciencias Agrícolas 4(6):909-920.

Padayatt S, Daruwala R, Wang Y, Eck PK, Song J Koh WS, Levine M (2001). Vitamin C: from molecular actions to optimum intake. In: Cadenzas E, Packer L (Eds). Handbook of Antioxidants. CRC press. Washington DC, USA pp 117-145.

Pandey P, Irulappan V, Bagavathiannan MV, Senthil-Kumar M (2017). Impact of combined abiotic and biotic stresses on plant growth and avenues for crop improvement by exploiting physio-morphological traits. Frontiers in Plant Science 8:537. https://doi.org/10.3389/fpls.2017.00537

Peyro H, Mirjalili SA, Kavoosi B (2017). Effect of salicylic acid and aloe vera gel on postharvest quality of table grapes (Vitis Vinifera). Trakia Journal of Sciences 15(2):154-159. https://doi:10.15547/tjs.2017.02.009 
Preciado-Rangel P, Salas-Pérez L, Gallegos-Robles MA, Ayala-Garay AV, Fortis-Hernández M, Murillo-Amador B (2018). Increasing doses of potassium increases yield and quality of muskmelon fruits under greenhouse. Horticultura Brasileira 36(2):184-188. https://doi.org/10.1590/hb.v36i2.1254

Preciado-Rangel P, Reyes-Pérez J, Ramírez-Rodríguez S, Salas-Pérez L, Fortis-Hernández M, Murillo-Amador B, Troyo-Diéguez E (2019). Foliar aspersion of salicylic acid improves phenolic and flavonoid compounds, and also the fruit yield in cucumber (Cucumis sativus L.). Plants 8(2): 44. https://doi:10.3390/plants8020044

Przybylska S (2020). Lycopene-a bioactive carotenoid offering multiple health benefits: a review. International Journal of Food Science \& Technology 55(1):11-32. https://doi.org/10.1111/ijfs.14260

Radwan DEM, Mohamed AK, Fayez KA, Abdelrahman AM (2019). Oxidative stress caused by Basagran herbicide is altered by salicylic acid treatments in peanut plants. Heliyon 5(5):e01791. https://doi:10.1016/j.heliyon.2019.e0179

Rai R (2020). Heat stress in crops: Driver of climate change impacting global food supply. In: Singh P, Singh R, Srivastava V (Eds). Contemporary environmental issues and challenges in era of climate change. Springer, Singapore pp 99-117. https://doi.org/10.1007/978-981-32-9595-7_5

Ríos-Osorio O, Chávez-Servia JL, Carrillo-Rodríguez JC (2014). Producción tradicional y diversidad de tomate (Solanum lycopersicum L.) nativo: un estudio de caso en Tehuantepec-Juchitán, México. [Traditional production and diversity of native tomato (Solanum lycopersicum L.): a study case in Tehuantepec-Juchitán, Mexico]. Agricultura, Sociedad y Desarrollo 11(1)35-51.

Rodríguez-Carpena JG, Morcuende D, Andrade MJ, Kylli P, Estévez M (2011). Avocado (Persea americana Mill.) phenolics, in vitro antioxidant and antimicrobial activities, and inhibition of lipid and protein oxidation in porcine patties. Journal of Agricultural and Food Chemistry 59(10):5625-5635. https://doi:10.1021/jf1048832

Semida WM, Abd El-Mageed TA, Mohamed SE, El-Sawah NA (2017). Combined effect of deficit irrigation and foliar-applied salicylic acid on physiological responses, yield, and water-use efficiency of onion plants in saline calcareous soil. Archives of Agronomy and Soil Science 63(9):1227-1239. https://doi.org/10.1080/03650340.2016.1264579

Saeed N, Khan MR, Shabbir M (2012). Antioxidant activity, total phenolic and total flavonoid contents of whole plant extracts Torilis leptophylla L. BMC Complementary and Alternative Medicine 12(1):221. https://doi:10.1186/1472-6882-12221

Sahu RK, Agrawal AK, Sinha G (2016). Extension of shelf life of custard apple (Annona squamosa L.) through post-harvest treatments. Madras Agricultural Journal 103:62-66.

Shah MS, Wang Y, Shu S, Zhong M, Chen Z, Wu J, Sun J, Guo S (2019). Exogenous salicylic acid increases the heat tolerance in tomato (Solanum lycopersicum L.) by enhancing photosynthesis efficiency and improving antioxidant defense system through scavenging of reactive oxygen species. Scientia Horticulturae 247:421-429. https://doi:10.1016/j.scienta.2018.12.047

Singleton V, Salgues M, Zaya J, Trousdale E (1985). Caftaric acid disappearance and conversion to products of enzymic oxidation in grape must and wine. American Journal of Enology and Viticulture 36(1):50-56.

SAS, Institute. 2004. SAS/STAT User's Guide. Version 9.1. SAS Institute. Cary, NC, USA.

Surh YJ (2008). NF-kappa B and Nrf2 as potential chemopreventive targets of some anti-inflammatory and antioxidative phytonutrients with anti-inflammatory and antioxidative activities. Asia Pacific Journal of Clinical Nutrition 17(1):269272.

Steiner AA (1984). The universal nutrient solution. In: Proceedings of the 6th International Congress on Soilless Culture. Lunteren, Netherlands pp 633-649.

Tareen MJ, Abbasi NA, Hafiz IA (2012). Postharvest application of salicylic acid enhanced antioxidant enzyme activity and maintained quality of peach cv. "Flordaking" fruit during storage. Scientia Horticulturae 142:221228. https://doi.org/10.1016/j.scienta.2012.04.027

Tokunaga T, Miyahara K, Tabata K, Esaka M (2004). Generation and properties of ascorbic acid-overproducing transgenic tobacco cells expressing sense RNA for l-galactono-1,4-lactone dehydrogenase. Planta 220(6):854863. https://doi:10.1007/s00425-004-1406-3

Tounekti T, Hernández I, Munné-Bosch S (2013). Salicylic acid biosynthesis and role in modulating terpenoid and flavonoid metabolism in plant responses to abiotic stress. In: Hayat S, Ahmad A, Alyemeni M (Eds). Salicylic acid. Springer, Dordrecht pp 141-162. 
Wada KC, Takeno K (2013). Salicylic acid-mediated stress-induced flowering. In: Hayat S, Ahmad A, Alyemeni M (Eds). Salicylic acid. Springer, Dordrecht pp 163-182.

Wang Z, Ma L, Zhang X, Xu L, Cao J, Jiang W (2015). The effect of exogenous salicylic acid on antioxidant activity, bioactive compounds and antioxidant system in apricot fruit. Scientia Horticulturae 181:113-120. https://doi.org/10.1016/j.scienta.2014.10.055

Wen T, Hao YJ, An XL, Sun HD, Li YR, Chen X, ... Lian ML (2019). Improvement of bioactive compound accumulation in cell cultures of Orostachys cartilaginous A. Bor. through elicitation with salicylic acid and effect of cell extract on bioactive activity. Industrial Crops and Products 139:111570. https://doi:10.1016/j.indcrop.2019.111570

Wilson DW, Nash P, Buttar HS, Griffiths K, Singh R, De Meester F, ... Takahashi T (2017). The role of food antioxidants, benefits of functional foods, and influence of feeding habits on the health of the older person: an overview. Antioxidants 6(4):81. https://doi.org/10.3390/antiox6040081

Wolfe KL, Liu RH (2007). Cellular antioxidant activity (CAA) assay for assessing antioxidants, foods, and dietary supplements. Journal of Agricultural and Food Chemistry 55(22):8896-8907. https://doi:10.1021/jf0715166

Xu M, Dong J, Wang H, Huang L (2009). Complementary action of jasmonic acid on salicylic acid in mediating fungal elicitorinduced flavonol glycoside accumulation of Ginkgo biloba cells. Plant, Cell \& Environment 32(8):960-967. https://doi.org/10.1111/j.1365-3040.2009.01976.x

Yactayo-Chang JP, Acosta-Gamboa LM, Nepal N, Lorence A (2017). The role of plant high-throughput phenotyping in the characterization of the response of high ascorbate plants to abiotic stresses. In: Hossain M, Munné-Bosch S, Burritt D, Diaz-Vivancos P, Fujita M, Lorence A (Eds). Ascorbic acid in plant growth, development and stress tolerance. Springer, Cham pp 321-354.

Yusuf M, Hayat S, Alyemeni MN, Fariduddin Q, Ahmad A (2013). Salicylic acid: physiological roles in plants. In: Hayat S, Ahmad A, Alyemeni M (Eds). Salicylic acid. Springer, Dordrecht pp 15-30.

Zhishen J, Mengcheng T, Jianming W (1999). The determination of flavonoid contents in mulberry and their scavenging effects on superoxide radicals. Food Chemistry 64:555-559. https://doi.org/10.1016/S0308-8146(98)00102-2
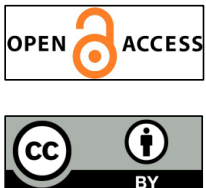

The journal offers free, immediate, and unrestricted access to peer-reviewed research and scholarly work. Users are allowed to read, download, copy, distribute, print, search, or link to the full texts of the articles, or use them for any other lawful purpose, without asking prior permission from the publisher or the author.

License - Articles published in Notulae Botanicae Horti Agrobotanici Cluj-Napoca are Open-Access, distributed under the terms and conditions of the Creative Commons Attribution (CC BY 4.0) License.

(c) Articles by the authors; UASVM, Cluj-Napoca, Romania. The journal allows the author(s) to hold the copyright/to retain publishing rights without restriction. 